\title{
Nadawanie sensu doświadczeniom
}

Zoltán Kövecses, Język, umyst, kultura. Praktyczne wprowadzenie, Towarzystwo Autorów i Wydawców Prac Naukowych UNIVERSITAS, Kraków 2011, s. 556

„Jakie relacje łączą system poznawczy, język i kulturę?"1. To jedno z pytań, jakie na samym początku stawia autor podręcznika Języka, umyst, kultura. Praktyczne wprowadzenie, Zoltán Kövecses. Jest on profesorem językoznawstwa na Uniwersytecie im. Eötvösa Loránda w Budapeszcie oraz autorem innej znanej książki - Metaphor: A Practical Introduction. Obecnie bada zagadnienia szeroko pojętego języka emocji, rolę metafor w codziennym życiu, a także związek między kulturą, umysłem i językiem. Jest jednym z głównych przedstawicieli lingwistyki kognitywnej, która narodziła się stosunkowo niedawno - w latach 70. XX wieku. Najogólniej mówiąc, założenia tej dziedziny nauki opierają się na rozwijanej wcześniej psychologii kognitywnej i sugerują, iż język jest ściśle powiązany z procesami zachodzącymi w naszym umyśle, dzięki którym postrzegamy świat w adekwatny sposób. Lingwistyka kognitywna wskazuje na relacje między językiem, informacjami, które gromadzimy i przetwarzamy w naszym umyśle oraz na ich wykorzystaniu do tworzenia naszego obrazu rzeczywistości.

Będąca podstawą niniejszej recenzji książka powstała w oparciu o wskazany wyżej nurt myślowy. Podjęte zostały w niej próby nazwania procesów, które wdrażamy (często nieświadomie),

\footnotetext{
${ }^{1}$ Z.K. Kövecses, Język, umyst, kultura. Praktyczne wprowadzenie, Towarzystwo Autorów i Wydawców Prac Naukowych UNIVERSITAS, Kraków 2011, s.17.
} 
aby nadać sens wydarzeniom naszego życia. Szczególne miejsce zajmują opisy i analizy zależności między trzema głównymi czynnikami kształtującymi nasz świat - językiem, kulturą i umysłem. Dzięki nim możemy „tworzyć znaczenia”2 . Z punktu widzenia autora, a mam nadzieję, że również czytelnika niniejszej książki najistotniejszym z podanych trzech czynników jest kultura. Co ważne, w innych podręcznikach przeznaczonych do studiowania lingwistyki kognitywnej, kwestie kulturowe zostały pominięte tutaj natomiast sa szeroko omawiane.

Dość dobrze zdajemy sobie sprawę z faktu, jak istotną rolę pełnił język w kształtowaniu dziejów i kultur na przestrzeni wieków. Może jednak problem należałoby odwrócić - być może to głównie kultura stanowiła zaczątek kształtowania się dziejów i poszczególnych języków. Tym, co wydaje się zrozumiałe jest fakt, iż jednym z celów i dążeń człowieka jest nadawania sensu i znaczenia rzeczywistości. Kövecses wyróżnia główne pojęcia, które, jak twierdzi, wykorzystujemy w tworzeniu obrazu świata. Są to: kategoryzacja, organizowanie wiedzy, myślenie metonimiczne (zastępowanie nazwy innym, podobnym określeniem, np. głowa zamiast rozum), myślenie metaforyczne, wyobrażenia, przestrzenie mentalne i integracja pojęciowa. Są to podstawowe określenia, które pozwalaja na głębsze zbadanie i przeanalizowanie problemu. Zbudowanie przez autora już na samym początku podstawowego schematu pojęciowego pozwala na dogłębną analizę, co jest dużym atutem omawianego podręcznika. Analiza ta ma jednak w dużej mierze charakter teoretyczny (co autor także podkreśla), sądzę jednak, iż właściwe zbadanie i przemyślenie problemu na gruncie teorii może doprowadzić do wniosków i obserwacji a posteriori. Podstawowe pojęcia, sformułowane na początku podręcznika, stanowią wystarczającą bazę do poznania problematyki przedstawionej przez autora. Jest to cenne z punktu widzenia amatora i kogoś, kto stawia pierwsze kroki w nauce lingwistyki kognitywnej i dziedzin jej pokrewnych.

\footnotetext{
${ }^{2}$ Tamże, s. 7.
} 
Niewątpliwie atutem prezentowanej książki jest uniwersalność stosowanych pojęć. Jak zaznaczyłam we wstępie, odnoszą się one przede wszystkim do lingwistyki kognitywnej, jednakże znajdują zastosowanie także w antropologii kulturowej, psychologii, językoznawstwie, czy nawet neurobiologii i filozofii umysłu. Jak czytamy w komentarzu znajdującym się na tylnej okładce: „Język, umyst, kultura jest pierwszą książką, która łączy wszystkie te trzy obszary badawcze" - co więcej, obraz wynikający z tego połacczenia jest spójny i przejrzysty. Nie ma tu mowy o bagatelizowaniu jakichkolwiek zagadnień, co dosyć często zdarza się w książkach, które łączą w sobie wiele tematów. Prezentowane w książce Kövecsesa kwestie są przez niego wyjaśniane - rozważania zaczynają się od kwestii ogólnych: tworzenie przez nas kategorii, którymi posługujemy się w świecie, następnie możliwości i etapy naszej interakcji ze światem, kwestie porządkowania wiedzy o świecie. Kolejno wyjaśnione są podstawowe zagadnienia związane z kontekstami kulturowymi, aż do bardziej szczegółowych opisów tworzenia metafor i znaczeń. Widoczna jest wyraźna spójność omawianych zagadnień oraz chronologia: jeśli przyjrzymy się naszemu życiu, zauważymy pewną analogię do przebiegu procesów, o których wspomniałam wyżej. Dostrzec można wyraźnie, iż autor posiada ogromne zaplecze naukowe - stosuje liczne porównania i z łatwością wykazuje związki między przytaczanymi teoriami a życiem.

To sprawia, że skłonna jestem polemizować z autorem, czy podręcznik ma charakter czysto-teoretyczny. Niekwestionowanym atutem podręcznika są bowiem ćwiczenia, zaproponowane pod koniec każdego rozdziału - właśnie po to, aby wiedzę zastosować w praktyce. Co ważne, zadania te są skonstruowane w taki sposób, aby każdy mógł je wykonać. Wymiar praktyczny przejawia się także w tym, iż schematy tworzenia znaczeń w języku odnoszą się nie tylko do nas samych i pozwalają zrozumieć siebie jako jednostkę posiadającą swoją własną kulturę ukształtowaną przez jezzyk, a także mającą konkretne miejsce w społeczeństwie, lecz także ułatwiają zrozumienie pewnych problemów i konfliktów, które towarzyszą naszemu życiu, zarówno na płaszczyźnie lokalnej 
jak i globalnej. Należałoby zwrócić także uwagę na styl i sposób przekazu myśli przez autora. Pomimo wyraźnie naukowego charakteru tego podręcznika i treści w nim zawartych, wydaje się on mieć znamiona książki popularnonaukowej.

Praktyczne zastosowanie wiedzy podanej w tej książce dostrzec można m.in. w podrozdziale "Codzienne rytuały" ${ }^{3}$, w którym autor pokazuje (za Johnsonem i Lakoffem), iż czynności, które wykonujemy każdego dnia bardzo często stanowią swego rodzaju fundament tworzenia pojęć (lub inaczej - pojęcia, które już posiadamy pozwalają nam poprzez codzienne czynności tworzyć kolejne nazwy i rozbudowywać już istniejące. W książce podawane są liczne przykłady takiego stosowania pojęć ale w celu ich poznania i późniejszego zastosowania, odsyłam do konkretnego rozdziału (tu: „Odwzorowania wewnątrz ram” $)^{4}$.

Podobnym przykładem zastosowania podanej w książce wiedzy do praktyki jest próba pokazania przez autora istnienia ścisłej zależności miedzy stosowanymi i tworzonymi przez nas pojęciami a naszym odbieraniem sztuki. Obcowanie z dziełami artystów może pomóc nam w tworzeniu nowej siatki pojęciowej, lepszym określeniu i opisaniu przez nas rzeczywistości. Takiemu stanowisku sprzyja założenie autora, iż dzieła sztuki przedstawiają obiektywną rzeczywistość, a zatem moga (a może i powinny) wywoływać racjonalne przemyślenia. Aby lepiej zrozumieć intencje autora, ponownie odsyłam do fragmentu książki ${ }^{5}$.

Ostatnim zagadnieniem, o którym chciałabym wspomnieć jest rola tworzenia metafor w codziennym języku. Autor podkreśla, iż wyrażenia językowe, którymi posługujemy się na co dzień, a które mają charakter metaforyczny (np. jestem GEODNY miłości, DAŁA SIĘ PONIEŚĆ uczuciom, WYCZERPAŁA SIE moja cierpliwość), także pomagają nam tworzyć ramy pojęciowe, w których poruszamy się, funkcjonujemy i określamy naszą rzeczywistość, a co za tym idzie także umożliwia nam to łatwiejsze

\footnotetext{
${ }^{3}$ Tamże, s. $171-172$.

${ }^{4}$ Tamże, s. 151-174.

${ }^{5}$ Tamże, s. 91-102.
} 
odnajdywanie się w nowej rzeczywistości i warunkach. Oczywiście nie można tego typu wyrażeń traktować jedynie w sensie dosłownym (z punktu widzenia logiki są one nierzadko abstrakcyjne), jednak stanowią one swego rodzaju pomost miedzy językiem, jaki tworzymy i doświadczeniami. Autor podkreśla, że rola metafor jest na tyle istotna, że nie tylko pomaga nam samym dostosować się do rzeczywistości, ale także może tworzyć nową kulturę (nie tyle istnieje tylko w naszym umyśle, co może zostać przeniesiona na nowe wzorce kulturowe) - autor podaje pojęcie modelu kulturowego, modelu kognitywnego bądź ICM.

Niniejszą książkę polecam każdemu. Przede wszystkim studentom, którzy pragną zaznajomić się z zagadnieniami dotyczącymi szeroko rozumianych nauk kognitywnych; nauczycielom i wykładowcom akademickim, którzy potrzebują usystematyzowania swojej wiedzy; psychologom, lingwistom, antropologom, aby dostrzegli wzajemne relacje między dyscyplinami naukowymi. Na końcu polecam tym wszystkim, którzy są amatorami w tej dziedzinie, lecz wykazują zainteresowanie przedstawioną tematyką lektura tej książki może być pomocna w uświadomieniu sobie, jak bardzo wszyscy jesteśmy zanurzeni i osadzeni w kulturze i jak bardzo język i umysł kształtują nasze postrzeganie i poznawanie świata.

Katarzyna Biel 